\title{
An introduction to national biographical dictionaries renovation
}

\author{
Mikel Urquijo \\ University of the Basque Country, Spain \\ mikel.urquijo@ehu.eus \\ Joseba Agirreazkuenaga \\ University of the Basque Country, Spain \\ joseba.agirreazkuenaga@ehu.eus
}

\begin{abstract}
The aim of this paper is to take part in the debate about the future of national biographies today. In this sense, we analyse national biographical dictionaries as instruments for the creation of national memory and as a foundation in the processes of building nation-states. We analyse the origin and development of national biographical dictionaries in the context of the evolution of biography. We initially observe the elements that condition dictionaries: the geographical and chronological framework in which they are developed, the criteria for selecting the personages whose biographies are to be written and for selecting biographers, the structure and sources of the biographies. At present, this model of dictionaries and national memory is being put into question by the emergence of new nationalisms and by the superseding of nations in new supranational bodies like the European Union. Finally, based on the above, we set out a proposal for renovating these works in the XXI century.
\end{abstract}

Keywords: national biography; national memory; open innovation; online editions

\section{Introduction}

The purpose of this paper is to participate in the current debate on the future of national biographical dictionaries. To that end, we make a first approach to the origin, meaning, and form of elaboration of these works in the XIX and XX centuries. On the basis of this initial reflection, we propose some considerations on their future, focusing on the meaning of these works, the selection of the personages included in them, the changes in the scientific structure of the institutions responsible for their elaboration, the public at which they are aimed, and the format (print or digital) of the dictionaries. 


\section{Biographies: evolution and method of collective biography}

Biography has been a subject of interest since classical antiquity. ${ }^{1}$ Biographies have evolved over the course of history depending on social changes and the transformation of their readers. It was in the Enlightenment era that great works that sought to gather all knowledge were elaborated, works that were published as encyclopaedias. ${ }^{2}$ Following the model of encyclopaedic knowledge, the first universal biographical dictionaries were elaborated. ${ }^{3}$ They sought to compile the biographies of all the notable people who had lived throughout time: »The idea of collecting the lives of all the notable people who had ever lived was formulated by the scholarly polymaths of early modern Europe, who sought to classify and organize knowledge at a time when the printing revolution was producing a deluge of undigested information. ${ }^{4}$ But the building of nation-states from the liberal revolutions onwards promoted a change in works of this type. The object of interest shifted from notable people in general to eminent people of the new nations, giving rise to national biographical dictionaries. These biographical dictionaries are »an integral part of the nation's mental furniture $«^{5}$ and form part of a project for the elaboration of the nation's history in which national archives and libraries were created and manuals were written to be taught in schools. ${ }^{6}$ In short, an imagined, concrete, and individualized representation was created, which conformed to the values of the bourgeoisie of a particular community that formed itself into a nation. The aim was to include the biographies of personages who represented the nation and its character in this process

1 Arnaldo Momigliano, The development of Greek biography, Harvard, University Press, 1971.

2 The model of universal encyclopedia in Denis Diderot, Jean Le Rond D'Alambert, Louis de Jaucourt, Encyclopédie ou Dictionnaire raisonné des sciences, des arts et des métiers, París-Neuchâtel, André Le Breton, 1751-1772, 28 vols.

3 The first works with these characteristics are: The Biographia Britannica, or the Lives of the most Eminent persons who have flourished in Great Britain and Ireland from the Earliest Ages down to the Present Times, London, 1747-1766, 7 vols, Alexander Chalmers, The General Biographical Dictionary: containing an historical and critical account of the lives and writings of the most eminent persons in every nation; particularly the British and Irish; from the earliest accounts to the present time / A new edition revised and enlarged by Alexander Chalmers, F.S.A, London, 1812-1817, 32 vols. and M. Hoefer, Nouvelle Biographie Générale depuis les temps les plus reculés jusqu'a nos jours, avec les renseignements bibliographiques et l'indication des sources a consulter, Paris, Firmin Didot Frères, Fils et Cie éditeurs, 1857-1866, 46 vols.

4 Keith Thomas, Changing Conceptions of National Biography. The Oxford DNB in Historical Perspective, Cambridge, University Press, 2005, p. 4.

5 Elizabeth Baigent, The geography of biography, the biography of geography: rewriting the Dictionary of National Biography, fournal of Historical Geography, 30, 2004, p. 531.

6 Ilaria Porciani and Jo Tollebeek (eds.), Setting the Standards. Institutions, Networks and Communities of National Historiography, New York, Palgrave MacMillan, 2012. 
of nation-building. ${ }^{7}$ The practice of Collective Biography was a practice linked to the European Cultural Legacy, given the important biographical tradition of the Western world from the XVI century with the creation of registers of biographical information. ${ }^{8}$

But our paper will not be focused on the origin and meaning of national biographical dictionaries, given that we can refer to the works of Professor Marcello Verga. ${ }^{9}$ We will simply point to four aspects of interest for making this reflection on the future of these dictionaries.

In the first place, the original meaning of these works should be recalled. These dictionaries are a part of the intellectual infrastructure in the process of defining and building nations in the contemporary age. The case of Belgium is probably one of the best examples for understanding this contribution to the process of nation-building. ${ }^{10}$ After attaining its independence, the new kingdom had to train its citizens facing the powerful neighbouring states, contributing to the creation of an identity and a collective memory in a plurilingual state. The Biographie Nationale ${ }^{11}$ formed part of the process of constructing the national history of the new state, with the goal of educating citizens, offering them the example of national heroes: »every nation needs its great men and its heroic past «.12

Elements that show us the national meaning of these dictionaries are the selection of the periods to be studied and the territories of origin of the personages included in the dictionaries. A connection with antiquity is sought in all cases, as an element for legitimizing the immortality of the nation in historical time. They provide a perspective on the history of each of the nations that begins in periods prior

7 Marcello Verga, Il dizionario è morto. Viva i dizionari! Note per una storia dei dizionari biografici nazionali in Europa, Storica, 40, 2008, pp. 10-11.

8 Joseba Agirreazkuenaga and Mikel Urquijo, »Collective Biography and Europe's Cultural Legacy«, The European Legacy. Toward New Paradigms, 20, 4, 2015, pp. 373-388.

9 Marcello Verga, Il dizionario si farà. Note per una storia del Dizionario biografico degli italiani, in: Carlo Ossola C, Marcello Verga, Maria Antonietta Visceglia (a cura di), Religione, cultura e politica nell'Europa dell'eta moderna. Gli amici a Mario Rosa, Firenze, Olschki, 2003, pp. 3-37, Verga, 2008, pp. 7-32, Marcello Verga, The Dictionary is Dead, Long Live the Dictionary! Biographical Collections in National Contexts, in: Ilaria Porciani and Jo Tollebeek (eds.), Setting the Standards. Institutions, Networks and Communities of National Historiography, New York, Palgrave MacMillan, 2012, pp. 89-104.

10 Marcello Verga, The Dictionary is Dead, Long Live the Dictionary! Biographical Collections in National Contexts, in: Ilaria Porciani and Jo Tollebeek (eds.), Setting the Standards. Institutions, Networks and Communities of National Historiography, New York, Palgrave MacMillan, 2012, pp. 89-104.

${ }^{11}$ Biographie Nationale, Bruxelles, H. Thiry Van Buggenhoudt, Impremeur-Editeur, 18661944,28 vols.

12 Quotation from E. Renan taken from Thomson, p. 10. 
to their constitution and existence. In Italy, this starts from the V century, ${ }^{13}$ in Spain the first printed version begins with the IV century $\mathrm{BC}^{14}$ and the current online version includes data from the VII century BC, ${ }^{15}$ in France with the age of the Gauls, ${ }^{16}$ etc. However, this national concept is not always made explicit in the introduction to the dictionary. Colin Matthew, editor of the Dictionary of National Biography, compared this Dictionary to a British postage stamp: »British stamps needed only the Queen's head and no national label: the DNB asserted nationality but carefully avoided defining it. ${ }^{17}$ There is an idea of the nation and of who forms part of it, but this is not made explicit when explaining how the Dictionary is elaborated.

Secondly, in continental Europe (Belgium, Austria, Germany, Italy...), these dictionaries are elaborated by public cultural institutions and financed with public funds, such as academies of history (Austria, Spain), committees created for the elaboration of biographical dictionaries (Belgium), etc. This assignment responds to a conception of knowledge limited to an enlightened elite and to the interest of the new liberal governments in promoting the elaboration of a national history in which they are portrayed. ${ }^{18}$

Thirdly, in general, we find works of great erudition that publish extensive biographies of particular personages in order to transform them into models for the new citizenry. A good example is the entry on Dante Alighieri in the Dizionario biografico degli italiani that takes up 55,224 words. ${ }^{19}$ The model of biography elaborated in this way tries to present the lives of the personages aimed at an erudite and specialized public.

Finally, the International Committee of Historical Sciences (CISH/ICHS), at its Congress held in Madrid in 1990, established biography as its major theme and called for a return to biography. But if we analyze the biographical dictionaries over time, we can state that this was a return to something that had never departed from, because dictionaries have been published continuously from the XIX century to the present day.

13 Dizionario biografico degli italiani, Roma Istituto della Enciclopedia Italiana, 1960, vol. I, p. VII.

14 Presentation of the Diccionario Biográfico Español at http://www.rah.es/pdf/InformacionDBE.pdf (21 March 2013).

15 Presentation of the Diccionario Biográfico Español http://dbe.rah.es/db e (4 May 2020).

${ }_{16}$ Jules Balteau, Marius Barroux and Michel Prévost (dir.), Dictionnaire de biographie française, Paris, Librairie Letouzey et Ané, 1933, vol. I, pp. V-VI.

17 Brian Harrison, Comparative biography and the DNB, Comparative Criticism, 25, 2004, p. 5.

18 Verga (2012) p. 97.

19 Originally written by Siro A. Chimenz and published in Volume II of the Dizionario. The same text has been reproduced in the current digital edition. 
Studia Iexicographica, 14(2020) 27, STR. 45-62

Mikel Urquijo, Joseba Agirreazkuenaga: An introduction to national biographical dictionaries renovation

\section{National biographical dictionaries ${ }^{20}$}

\begin{tabular}{|c|c|c|c|}
\hline Country & Title & Vols. & Edition \\
\hline \multirow[t]{3}{*}{ Sweden } & Biographiskt Lexikon öfver namnkunnige Svenskamän & 23 & $1835-1857$ \\
\hline & Svenskt biografiskt lexikon & 10 & $1857-1907$ \\
\hline & Svenskt biografiskt lexikon & 32 & $1918-2002$ \\
\hline \multirow[t]{3}{*}{ Holland } & Biografisch Woordenboek Der Nederlanden & 24 & $1852-1878$ \\
\hline & Nieuw Nederlandsch Biografisch Woordenboek & 11 & 1911-1937 \\
\hline & Biografisch Woordenboek Van Nederland & 5 & 1979-2001 \\
\hline \multirow[t]{3}{*}{ Austria } & $\begin{array}{l}\text { Der grosse Oesterreichische Hausschatz: biographisches Lexicon des } \\
\text { Kaiserthums Oesterreich }\end{array}$ & 60 & $1856-1891$ \\
\hline & Neue Österreichische Biographie Ab 1815: Grosse Österreicher & 22 & $1923-1987$ \\
\hline & Österreichisches Biographisches Lexikon 1815-1950 & 12 & $1957-2010$ \\
\hline \multirow[t]{3}{*}{ Belgium } & Biographie Nationale & 28 & 1866-1944 \\
\hline & Suplementos a la Biographie Nationale & 16 & 1957-1986 \\
\hline & Nouvelle Biographie Nationale & 10 & $1988-2013$ \\
\hline \multirow[t]{2}{*}{ Germany } & Allgemeine Deutsche Biographie & 56 & 1875-1912 \\
\hline & Neue Deutsche Biographie & 21 & $1953-2010$ \\
\hline \multirow{2}{*}{$\begin{array}{l}\text { United } \\
\text { King- } \\
\text { dom }\end{array}$} & Dictionary of National Biography & $63+3$ & $1885-1901$ \\
\hline & Oxford Dictionary of National Biography & 60 & 2004 \\
\hline Norway & Norsk Biografisk Leksikon & 19 & 1921-1983 \\
\hline \multirow[t]{2}{*}{ Slovenia } & Slovenski biografski leksikon & 16 & 1925-1991 \\
\hline & Novi Slovenski biografski leksikon & 3 & 2013- \\
\hline \multirow[t]{3}{*}{ USA } & Dictionary of American Biography & 20 & 1928-1937 \\
\hline & American National Biography & 24 & 1999 \\
\hline & American National Biography on-line & online & $2000-$ \\
\hline France & Dictionnaire de Biographie Française & 19 & 1933-2009 \\
\hline \multirow[t]{2}{*}{ Denmark } & Dansk biograhisk Leksikon & 27 & 1933-1944 \\
\hline & Dansk biograhisk Leksikon & 16 & 1979-1984 \\
\hline Poland & Polski Słownik Biograficzny & 53 & 1935-2020 \\
\hline $\begin{array}{l}\text { Luxem- } \\
\text { bourg }\end{array}$ & $\begin{array}{l}\text { Biographie nationale du Pays de Luxembourg depuis ses origines } \\
\text { jusqu'a nos jours }\end{array}$ & 11 & 1949-1975 \\
\hline Italy & Dizionario biografico degli italiani & 75 & $1960-2011$ \\
\hline
\end{tabular}

20 This list does not include all the dictionaries produced throughout the world. It is only intended to show their continuity, with successive republications or revisions or the production of new works, from their origins in 1835 to the present. 


\begin{tabular}{l|l|l|l|}
\hline Canada & $\begin{array}{l}\text { Dictionary of Canadian Biography-Dictionnaire Biographique du } \\
\text { Canada }\end{array}$ & $\begin{array}{l}14 \\
\text { Cd }\end{array}$ & $\begin{array}{l}1966-1989 \\
2000\end{array}$ \\
\hline $\begin{array}{l}\text { Australia } \\
\text { Croatia }\end{array}$ & $\begin{array}{l}\text { Australian Dictionary of Biography } \\
\text { Hrvatski biografski leksikon }\end{array}$ & 17 & $1966-2011$ \\
\hline $\begin{array}{l}\text { New } \\
\text { Zealand }\end{array}$ & Dictionary of New Zealand Biography & 8 & $1983-$ \\
\hline Finland & Suomen Kansallsbiografia & online & $2015-$ \\
\hline Ireland & Dictionary of Irish biography: from the earliest times to the year 2002 & 5 & $1990-2000$ \\
\hline Spain & Diccionario biográfico español & 10 & $2002-2007$ \\
\hline & Diccionario biográfico español on-line & 50 & $2009+2018$ \\
\hline
\end{tabular}

Successive series of a dictionary have been published in some countries, expanded and updated to the present (Sweden, Holland, Austria and Belgium); while new projects have been started in the last decade in others (Spain, Ireland, Finland). In general, we can say that these projects have maintained continuity since their beginning.

\section{The renovation of the dictionaries}

However, in the XXI century, a significant change can be observed in these dictionaries. Firstly, the consolidation of the democratic processes and states has contributed to a widening of the liberal concept, with the introduction of new actors and protagonists in the dictionaries, in particular the visibility of women. On the other hand, political changes, in the European case due the development of the European Union, social changes with the spread of literacy throughout the XX century, technological changes with the development of the Internet, and changes in the concept of innovation with the development of $\mathrm{H}$. W. Chesbrough's concept of open innovation $^{21}$ open up new development possibilities for this type of work in the process of their renovation.

Starting from these new elements, we suggest a reflection on the renovation of the biographical dictionaries based on five aspects: the meaning of the works, the choice of the personages to be included through the incorporation of thematic biographical dictionaries, the opening up of the institutions that produce them, the public they are aimed at, and the format (print or digital) of the dictionaries.

In relation to the meaning of these works, we can note a significant change that has taken place from their beginnings to the present time. In the XIX century,

${ }^{21}$ Henry W. Chesbrough, Open Innovation, Harvard Business School Publishing Corporation, 2006. 
these works were conceived as a contribution to the elaboration of national history ${ }^{22}$ in the context of the creation of the new nation-states. But this concept of national biographies must be rethought in XXI-century Europe.

At present, the process of building the European Union places the XIX-century idea of nation-states in question. ${ }^{23} \mathrm{~A}$ large part of the elements that made up the essence of the nation-states of the XIX century have become European policies. An example would be the currency and its management, or the direction of economic policy. Decisions in relation to these questions are no longer national, or at least not solely national, but have become European. ${ }^{24}$

On the other hand, the biographical dictionaries refer to eminent people who have had an influence on the life of the nation. When we think about these people today, we also go beyond the national framework. It is unquestionable that personages like those in charge of the economic decisions of the European Union or the European Central Bank have a great influence on the lives of all Europeans, above the decisions of their own governments. Should these personages be included in various national dictionaries? Should we begin thinking about how to construct a European biographical dictionary?

But facing this process of building Europe, there are political formations that oppose this in a large number of member states, demanding the renationalization of politics and the strengthening of the existing nation-states, and even call for leaving the European Union. At the same time, in some of these states, the creation of new states in the European Union is being proposed on the basis of national claims. In short, the idea of the nation is still alive in Europe and is one of the reasons why the biography of the nation is still alive. It is not by chance that the most recent dictionaries were published in Spain, where the national debate has gained strength in recent years, or in Ireland, where it is also a topical issue.

The debate on the meaning of national biography projects is closely linked to the criterion for the inclusion of personages in these works. The selection of personages to be included in the dictionaries is one of the main problems faced by those who have directed the elaboration of these works. The criterion employed over the course of the XIX century and a large part of the XX was the inclusion of eminent people in the history of the new nations.

22 Ilaria Porciani and Jo Tollebeek (eds.), Setting the Standards. Institutions, Networks and Communities of National Historiography, New York, Palgrave MacMillan, 2012.

23 Desmond Dinan, Origins and Evolution of the European Union, Oxford, Oxford University Press, 2014 and Chiara Bottici and Benoît Challand, Imagining Europe. Myth, Memory, and Identity, Cambridge, Cambridge University Press, 2013.

24 Mikel Urquijo, National biography and national memory in the XXI century, Storia della Storiografia, 66, 2, 2014, pp. 37-52. 
In Belgium it included »Belges ayant joui d'une certaine notoriété/Belgians who have enjoyed a certain notoriety « (1866), ${ }^{25}$ in Scotland »eminent Scotsmen« (1874), ${ }^{26}$ in England »noteworthy inhabitants of the British Islands and the Colonies « (1885), ${ }^{27}$ in Italy »tutti coloro che hanno avuto un particolare rilievo nei vari aspetti e momento della vita e della civiltà italiana dal V secolo ai nostri giorni/all those who have in some way stood out in different aspects and moments of Italian life and civilization from the V century to the present day « (1960) ${ }^{28}$ in Canada »all noteworthy inhabitants of the Dominion of Canada « (1966), ${ }^{29}$ and in Spain »all those who played a prominent part in administration and government, in warfare and peaceful activities, in the arts, in letters and sciences in the Hispanic territories, in those that lie overseas and beyond the Pyrenees, which formed part of what is usually termed the 'Hispanic Monarchy' ${ }^{30}$

But although we continue to talk of eminent or outstanding people, the concept of eminence has changed over time. ${ }^{31}$ In the XIX century, the personages included in these dictionaries were people who formed part of the country's political, economic, cultural and social elite, with little room for personalities who nowadays have an important social presence, like sportspeople, singers, or actors.

On the other hand, nowadays there are works like the Australian Dictionary of Biography, which include people who, while not prominent, represent important types in the nation's life: »What has changed, therefore, is not the intellectual rationale or method of compilation but our perspective on what constitutes influence and historical value. $1^{32}$ Another interesting example where the classical criterion for inclusion has been altered is the Dictionary of New Zealand Biography, in which a new publication has been included, A People's History, ${ }^{33}$ which includes the biographies of subaltern people who bear no relation to the classical concept of eminen-

25 Lavalleye, p. 25.

26 Thomson, vol. VI, p. VI.

27 Leslie Stephen and Sidney Lee (eds.), The Dictionary of National Biography, Oxford, Univer-

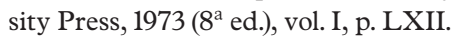

28 Dizionario biografico degli italiani, vol. I, p. XVII.

${ }^{29}$ George W. Brown (ed.), Dictionary of Canadian Biography, Toronto, University Press, 1966, vol. I, p. XVI.

30 Diccionario Biográfico Español, Madrid, Real Academia de la Historia, 2009, vol. I, p. 12. 1994, p. 49.

31 Peter Lastlett, The Dictionary of National Biography: Missing Persons, History Today, 44, 1 ,

32 Philip Carter, From the Cracks of History, History Today, 54, 10, 2004, pp. 18-20.

33 William H. Oliver, A People's History, Illustrated Biographies from The Dictionary of New Zealand Biography, Volume One 1796-1869, Wellington, 1992. 
ce. These are people who exemplify »qualities of human vitality, resilience and endurance, a quirky dignity among those of all sorts and condition who strove to stand upright in a strange land $\aleph^{34}$ and the concept of national biography is thus broadened. ${ }^{35}$

In all these works, there is a scant presence of women ${ }^{36}$ amongst the entries, which has led their editors to give specific consideration to this question. At the Oxford Dictionary of National Biography, a specific editor who is responsible for the inclusion of women's biographies in all thematic areas ${ }^{37}$ has been appointed to try and alleviate this lack.

This broadening of the criterion for including personages, paying attention to the presence of women, new »eminent« people like sportspersons or actors, or people who have helped to shape national identity (Australia, New Zealand), leads to a revision of the editorial structure and format of the dictionaries.

From their beginnings, the dictionaries in continental Europe were elaborated by public institutions linked to the state. These could be academies of history, as in the case of Austria, biography committees created for that purpose, as in Belgium, etc. In short, institutions in which a small group of academics designed and directed the project, although numerous collaborators were involved in writing up the biographies. At present, the inclusion of personages from other groups, like actors, sportspersons, technologists, etc., makes it necessary to go beyond the field of these institutions in designing and editing these projects. As $\mathrm{H}$. W. Chesbrough teaches us, knowledge and innovation cannot be generated in closed institutions. The idea of open innovation leads us to seek contributions to the projects of generating knowledge outside these »temples of knowledge«. In short, this structure must be reconsidered and opened up to other people. A good model of this process of opening up is that of the American National Biography, in which the editorial structu$\mathrm{re}^{38}$ has 265 academics from different universities in the United States: a general editor, an editorial committee of 14 people, and 19 thematic advisory committees with 250 members. These committees have a double structure. Among them, 6 deal with the history of the United States divided chronologically (until 1763, 1763-1850, 1850-1878, 1878-1914, 1914-1945, 1945-1990), while 12 are thematic (Religion; Educa-

34 Baigent, p. 541.

35 Ibid., p. 540.

36 Patricia Grimshaw, Female Lives and the Tradition of Nation-Making, in: Iain McCalman, Jodi Pavery J and Misty Cook (eds.), National Biographies E National Identity. A Critical Approach to Theory and Editorial Practice, Canberra, The Australian National University, 1996, pp. 35-53.

37 http:/global.oup.com/oxforddnb/info/print/intro/intro3/ (26 February 2014).

38 http://www.anb.org/editors_2012.html (26 February 2014). 
tion; Business; Law and the Judiciary; Medicine; Science and Technology; Social Sciences; Social Reform; Literature, Journalism and Popular Writing; Art, Architecture and Applied Arts; Performing Arts; Sports). Finally, there is an editorial committee for miscellanea that includes themes not covered by the aforementioned committees. In short, this is an extensive research network through which the activity of hundreds of writers from different universities in the United States is structured.

With this new editorial structure, a different vision of our past is provided through the work of people from different fields of knowledge, one that surpasses the limits of previous models.

Another important point of reflection on biographical dictionaries today is the public at which they are aimed.

In the XIX century, a significant part of the population was illiterate, so those who made the biographical dictionaries thought of a cultured public that was interested in reading the biographies of members of the political, economic, and cultural elite of the new nation-states.

Nowadays, the situation has changed considerably. The adult population is literate in the developed countries and all the population can read, even if they do not do so. Therefore, there is a new potential public for these works. But our question is whether the dictionaries have been adapted to these new publics.

The cultural level of the possible readers is not the same, and their way of reading is different from earlier periods. Nowadays, the development of the Internet and the new digital publications mean that the form of reading is different and encyclopedias and the mass media are adapting to »reading online«. In online publications, brief texts are included, with links between them for broadening information. Links are also included to other written, audio, or audio-visual sources.

Facing this reality, the question we pose is whether biographical dictionaries should be adapted to these new forms of reading. ${ }^{39}$ Should their length be reduced? Should different versions of the same content be prepared: the classical version and another briefer, visual one?

This question is linked to that of the authorship of the different entries. Specialists are assigned to write up the entries for the dictionaries, and they are generally members of the academic world. Nowadays, the experience of Wikipedia has contributed to spreading the concept of the open dictionary, to which anyone can

39 David Stoker, The new Dictionary of National Biography and the future of the printed reference work, Fournal of Librarianship and Information Science, 32, 1, 2000, pp. 1-3. 
contribute as a writer. One difference between wikis and biographical dictionaries is the academic authorship of the entries in the latter. Additionally, in the type of dictionaries we are analysing, the biographies are reviewed by editorial committees that evaluate their suitability prior to publication. Collaborative biography is valid on condition that certain authors take responsibility for the content and updating is done with their agreement, something that is not guaranteed in the case of Wikipedia.

There is no simple answer to these questions. How can we reconcile the opening up of these works to the broad public with the erudition that has characterized these projects?

Another question to be rethought, which is linked to the aforementioned, is the format (print or digital) of the dictionaries.

Until the XXI century, dictionaries were published on paper with biographies arranged alphabetically, except in the case of Canada, where the arrangement was chronological. ${ }^{40}$ In recent years, all works published in several volumes that require periodical updating are being transferred to a digital format, first a CD-ROM edition, and later an online edition. A good example for understanding this change is The Dictionary of National Biography that has been extended with successive updates that have doubled the number of volumes since its original publication. ${ }^{41}$

This change of format can be explained by the high cost of printed editions and the possibility of swifter and more economical updating and correction. ${ }^{42}$ But, while these reasons are important, they are not the only motive for the dictionaries' change of format. With digital publishing, we can consider a deeper change in the dictionaries. This new format makes it possible to link biographies to other biographies in the dictionary, to other digital works like encyclopedias or to websites that include texts, images and audio documents related to the issue in question. This

40 The volumes were organized as follows: Vol. I, 1000-1700 / Vol. II, 1701-1740 / Vol. III, 17411770 (1974) / Vol. IV, 1771-1800 / Vol. V, 1801-1820 / Vol. VI, 1821-1835 / Vol. VII, 1836-1850 / Vol. VIII, 1851-1860 / Vol. IX, 1861-1870 / Vol. X, 1871-1880 / Vol. XI, 1881-1890 / Vol. XII, 1891-1900 / Vol. XIII, 1901-1910 / Vol. XIV, 1911-1920. Brown (1966-1989).

41 The Dictionary of National Biography was published in 22 volumes (1885-1901). Subsequently, one volume of updates was published every decade until 1980, and from then onwards every five years. The year 1993 saw the addition of a new volume, The Dictionary of National Biography. Missing Persons. This was dedicated to people who, from the start of history, had not previously been included and who were considered worthy of inclusion at that time (on these volumes, see Missing Persons /1990/). This was a quantity of volumes that made the work barely manageable. The new 2004 version had 60 volumes.

42 Brian Harrison, National biography for a computer age, History Today, 51, 8, 2001, pp. 16-18 and Arnold D. Harvey, The Oxford Dictionary of National Biography, History Today, 54, 10, 2004, pp. 58-61. 
is already possible with the American National Biography and the Oxford Dictionary of National Biography, which are interlinked and also linked to the Encyclopaedia Britannica. In the American National Biography, we also have the option of carrying out searches based on the profession, gender, dates of birth and death, etc. of the personages we are interested in. That is, the static dictionary printed on paper becomes an enormous biographical database enabling more efficient use to be made of the information than was the case in the printed version.

Based on this possibility of linking different dictionaries, can we consider building a dictionary that extends beyond the nation? Can we envisage a European dictionary conceived on the basis of a future link amongst national dictionaries? Are we returning to the idea of universal biographical dictionaries of the Age of Enlightenment? Will the dictionary become a digital encyclopedia offering the possibility of an almost limitless widening of the information on biographies? ${ }^{23}$

The new digital formats open up the possibility of transforming dictionaries in such a way that they can be aimed at different publics based on different levels. A briefer article that contains essential information on the subject of the biography can be written for the broad public, with the possibility of broadening this information through different links. A second, more extensive text would be for specialists; this would be similar to current biographical entries but also include links to other content related to the subject of the biography and to sources, through access to biographical archives within a transnational perspective. ${ }^{44}$ And, finally, a third file designed as a database, with a closed thesaurus, making it possible for researchers to process data on groups of personages. In this way, a dictionary constructed on three levels would appeal to a broader readership.

\section{Conclusions}

The first question we ask is whether it makes sense to propose a national biographical dictionary today, when the nation coexists with other supranational, political forms of organization ${ }^{45}$ and there is reflection on forms of global government.

43 James Raven, The Oxford Dictionary of National Biography: Dictionary or Encyclopedia?, The Historical fournal, 50, 4, 2007, pp. 991-1006.

44 A project along these lines is that of Gruyter Saur (http://www.degruyter.com/view/serial/35520), who is developing a World Biographical Information System Online, in which organized biographical sources are provided though biographies with the following fields: name, gender, year or birth/death, year cited, occupation and occupation classification, short title of original source and localization of microfiche in the Biographical Archive.

45 Hannes Schweiger, Global Subjects: The Transnationalisation of Biography, Life Writing, 9, 3, 2012, pp. 249-258. 
It is true that these works respond to a certain period of contemporary history and the concern of »nation builders « to create a framework of representation and legitimize their existence. But it is also clear that constructing these national biographies by defining the nation in time and space from the present to the past, as has been the case, is something that we must reconsider.

The lack of a clear definition of the nation in the majority of these works is proof of the relevance of this reflection. An interesting reflection on this question is provided in the introduction to the Oxford Dictionary of National History: »the DNB asserted nationality but carefully avoided defining it ${ }^{46}{ }^{46}$ This intentional lack of definition permits the inclusion of people who lived in the territory of Great Britain prior to the existence of a recognizable state and the presence of people originating from all the British and overseas territories.

This proves especially important in countries that have dominated a colonial empire that is nowadays no longer existent, like Spain, France, or the United Kingdom. In the case of the new nations, the question is different. The American National Biography understands an American to be "someone whose significant actions occurred during his or her residence within what is now the United States or whose life or career directly influenced the course of American history « ${ }^{47}$ However, in these cases doubts arise over the treatment given to the inhabitants of those territories prior to the creation of today's states.

This initial reflection on the framework of national biographies conditions the selection of the personages to be included in them or, in other words, the criterion for inclusion/exclusion in these works.

Firstly, it is necessary to revise the dictionaries to try and fill gaps that might be detected. We have already mentioned the limited female presence ${ }^{48}$ in the majority of these works, and that of prominent people from peripheral regions, and also that of personages not considered eminent according to the XIX-century parameters within which these projects were planned. Dictionaries must be opened up to difference, that is, to those who do not form part of the elite conceived in the conventional sense, ${ }^{49}$ in the words of Colin Matthew, editor of the Oxford Dictionary of

46 Cited in Principles of inclusion, at http://www.oup.com/oxforddnb/info/print/intro/intro2/ (14 March 2013).

47 Preface, American National Biography online at http://www.anb.org/foreward.html (11 March 2013).

48 Grimshaw, pp. 35-53.

49 James Walter, Seven questions about National Biography, in: Iain McCalman, Jodi Pavery J and Misty Cook (eds.), pp. 16-34. 
National Biography, »the new dictionary is not merely a roll-call of the great and the good, but also a gallimaufry of the eccentric and the bad.$^{50}$

On the other hand, close consideration should be given to the proposal made in Australia, New Zealand, and the United States to include ordinary men and women in renovating the dictionaries, people who represent a large part of the anonymous citizenry of the nation.

In any case, this change of direction in the selection of personages for inclusion is not a simple question, as shown by J. Raven's criticisms of the new Oxford Dictionary of National Biography. ${ }^{51}$ This leads us to consider that the process of reflecting on the dictionary's purpose must be a permanently open one, in a process of continuous renovation.

To advance this renovation, it seems suitable to organize the work in thematic subprojects that take account of chronology and space. The project must be opened to academic contributions from the entire territory that the dictionary is concerned with. Interesting examples can be seen in the case of the American National Biography and in the Oxford Dictionary of National Biography, which develop the paradigm of open innovation both in their editorial structure and by opening up consultation to include a large number of people.

On the other hand, dividing the updating process into partial works makes it possible to rethink the biographies in a more homogeneous way, so that the resulting biographies show greater coherence and can be exploited subsequently, as J. Maitron proposes in the revision of the Dictionnaire Biographique du Mouvement Ouvrier Français. $^{52}$

The result of these subprojects will shape the new dictionary, as has occurred in the United Kingdom,53 this will multiply the number of biographies, which will inevitably lead to its digital publication. Printed national biographical dictionaries are currently not viable given the enormous costs of publication, their limited capacity for updating and correction, and their limitations for organizing information. A good model, due to the possibilities it offers, is that of the American National Biography.

Digital publishing enables the work to undergo a continuous process of revision, correction and updating at a reduced cost. It broadens the possibilities for sear-

50 Cited in Principles of inclusion, at http://www.oup.com/oxforddnb/info/print/intro/intro2/ (14 March 2013).

51 Raven, pp. 991-1006.

52 Jean Maitron (dir.), Dictionnaire Biographique du Mouvement Ouvrier Français [CD-Rom], Paris, Ed. de l'Atelier, 1997.

53 Colin Matthew, The new Dictionary of National Biography, History Today, 43, 1993, pp. $10-13$. 
ching, from the traditional alphabet to searches by term and chronology throughout the text, not only in the titles of the biographical entries. It enables the simple inclusion of images and links to other terms within the same dictionary, to digitized documents in thematic portals, etc. In short, it widens the possibilities of information beyond the dictionary itself, for people who want to acquire deeper knowledge of the personages or of themes linked to them. Will dictionaries end up being transformed into encyclopedias?

Another question to consider closely is the length of the biographies. Facing the option of choosing between extensive biographies aimed at specialists or briefer ones aimed at the general public, it would be possible to opt for a dictionary with different levels, where there is room for both options.

In conclusion, biographical dictionaries must be rethought with respect to their object of study, the criteria for including the personages to be studied, the size and model of the biographical entries and the format to be used. In short, we must use the instruments of the XXI century to re-elaborate an object of study from the XIX century. 


\section{REFERENCES}

Agirreazkuenaga, Joseba, Urquijo, Mikel (2015). Collective Biography and Europe's Cultural Legacy. The European Legacy. Toward New Paradigms, 20-4, pp. 373-388.

American National Biography online (http://www.anb.org).

Baigent, Elizabeth (2004). The geography of biography, the biography of geography: rewriting the Dictionary of National Biography. Fournal of Historical Geography, 30, p. 531.

Balteau, Jules, Barroux, Marius, Prévost, Michel (dir.) (1933-2004). Dictionnaire de biographie française. Paris: Librairie Letouzey et Ané, 20 vols.

The Biographia Britanica, or the Lives of the most Eminent persons who have flourished in Great Britain and Ireland from the Earliest Ages down to the Present Times (1747-1766). London: 7 vols,

Biographie Nationale (1866-1944). Bruxelles: H. Thiry Van Buggenhoudt, Impremeur-Editeur, 28 vols.

Bottici, Chiara, Challand, Benoît (2013). Imagining Europe. Myth, Memory, and Identity. Cambridge: Cambridge University Press.

Brown, George W. (ed.) (1966-1988). Dictionary of Canadian Biography / Dictionnaire Biographique du Canada. Toronto-Quebec: University of Toronto Press-Les Presses de l'Université Laval, 14 vols.

Carter, Philip (2004). From the Cracks of History. History Today, 54-10, pp. 18-20.

Chalmers, Alexander (1812-1817). The General Biographical Dictionary: containing an historical and critical account of the lives and writings of the most eminent persons in every nation; particularly the British and Irish; from the earliest accounts to the present time. London: 32 vols.

Chesbrough, Henry W. (2006). Open Innovation. Harvard Business School Publishing Corporation.

Diccionario Biográfico Español (http://www.rah.es).

Diccionario Biográfico Español (2009). Madrid: Real Academia de la Historia, 50 vols.

Diderot, Denis, D’Alambert, Jean Le Rond, Jaucourt, Louis de (1751-1772). Encyclopédie ou Dictionnaire raisonné des sciences, des arts et des métiers. París-Neuchâtel: André Le Breton, 28 vols.

Dinan, Desmond (2014). Origins and Evolution of the European Union. Oxford: Oxford University Press. Dizionario biografico degli italiani (1960-2020). Roma: Istituto della Enciclopedia Italiana, 100 vols.

Grimshaw, Patricia (1996). Female Lives and the Tradition of Nation-Making. In: McCalman, Iain, Pavery, Jodi and Cook (eds.). National Biographies \& National Identity. A Critical Approach to Theory and Editorial Practice. Canberra: The Australian National University, pp. 35-53.

Harrison, Brian (2001). National biography for a computer age. History Today, 51-8, pp. 16-18.

Harrison, Brian (2004). Comparative biography and the DNB. Comparative Criticism, 25, pp. 3-26.

Harvey, Arnold D. (2004). The Oxford Dictionary of National Biography. History Today, 54-10, pp. $58-61$.

Hoefer, M. (1857-1866). Nouvelle Biographie Générale depuis les temps les plus reculés jusqu'a nos jours, avec les renseignements bibliographiques et l'indication des sources a consulter. Paris: Firmin Didot Frères, Fils et Cie éditeurs, 46 vols.

Lastlett, Peter (1994). The Dictionary of National Biography: Missing Persons. History Today, 44-1, p. 49 .

Maitron, Jean (dir.) (1997). Dictionnaire Biographique du Mouvement Ouvrier Français [CD-Rom]. Paris: Ed. de l'Atelier.

Matthew, Colin (1993). The new Dictionary of National Biography. History Today, 43, pp. 10-13.

Momigliano, Arnaldo (1971). The development of Greek biography. Harvard: University Press. 
Oliver, William H. (1992). A People's History, Illustrated Biographies from The Dictionary of New Zealand Biography, Volume One 1796-1869, Wellington.

Oxford Dictionary of National Biography (http://www.oxforddnb.com).

Porciani, Ilaria, Tollebeek, Jo (eds.) (2012). Setting the Standards. Institutions, Networks and Communities of National Historiography. New York: Palgrave MacMillan.

Raven, James (2007). The Oxford Dictionary of National Biography: Dictionary or Encyclopedia?. The Historical fournal, 50-4, pp. 991-1006.

Schweiger, Hannes (2012). Global Subjects: The Transnationalisation of Biography. Life Writing, 9-3, pp. 249-258.

Stoker, David (2000). The new Dictionary of National Biography and the future of the printed reference work. Fournal of Librarianship and Information Science, 32-1, pp. 1-3.

The Dictionary of National Biography (1885-1901). London: Smith, Elder \& Co., 22 vols.

Thomas, Keith (2005). Changing Conceptions of National Biography. The Oxford DNB in Historical Perspective, Cambridge: University Press.

Urquijo, Mikel (2014). National biography and national memory in the XXI century. Storia della Storiografia, 66-2, pp. 37-52.

Verga, Marcello (2003). Il dizionario si farà. Note per una storia del Dizionario biografico degli italiani. In: Ossola Carlo, Verga, Marcello, Visceglia, Maria Antonietta (a cura di), Religione, cultura e politica nell'Europa dell'eta moderna. Gli amici a Mario Rosa, Firenze. Olschki, pp. 3-37.

Verga, Marcello (2008). Il dizionario è morto. Viva i dizionari! Note per una storia dei dizionari biografici nazionali in Europa. Storica, 40, pp. 7-32.

Verga, Marcello (2012). The Dictionary is Dead, Long Live the Dictionary! Biographical Collections in National Contexts. In: Porciani, Ilaria and Tollebeek, Jo (eds.). Setting the Standards. Institutions, Networks and Communities of National Historiography, New York: Palgrave MacMillan, pp. 89-104.

Walter, James (1996). Seven questions about National Biography. In: McCalman, Iain, Pavery, Jodi and Cook (eds.). National Biographies $\mathcal{G}$ National Identity. A Critical Approach to Theory and Editorial Practice. Canberra: The Australian National University, pp. 16-34. 


\title{
UVOD U OBNOVU NACIONALNIH BIOGRAFSKIH LEKSIKONA
}

\author{
Mikel Urquijo \\ Sveučilište Baskije, Španjolska \\ mikel.urquijo@ehu.eus \\ Joseba Agirreazkuenaga \\ Sveučilište Baskije, Španjolska \\ joseba.agirreazkuenaga@ehu.eus
}

Sažetak: Svrha je ovoga rada sudjelovati u raspravi o budućnosti nacionalnih biografija u današnjem vremenu. Stoga analiziramo nacionalne biografske leksikone kao oruđa za stvaranje nacionalnoga sjećanja i temelja u procesu izgradnje nacija-država. Analiza obuhvaća postanak i razvoj nacionalnih biografskih leksikona u kontekstu razvoja biografije. Najprije promatramo elemente koji uvjetuju leksikone, geografske i kronološke okvire u kojima nastaju, kriterije za izbor ulaznika i suradnika, strukturu i izvore biografskih članaka. U današnje se vrijeme ovaj model leksikona i nacionalnoga sjećanja dovodi u pitanje zbog pojave novih nacionalizama i zamjene nacija novim nadnacionalnim tijelima, poput Europske unije. Zaključno, na temelju prethodno navedenog, donosimo prijedlog za obnovu ovakvih djela u XXI. stoljeću.

Ključne riječi: nacionalna biografija; nacionalno sjećanje; otvorene inovacije; online izdanja 